\title{
Alunos de CAP e BEP face aos conteúdos escolares contribuição para uma sociologia das formas de relação com os saberes
}

\author{
AZIZ JELLAB
}

RESUMO: O artigo investiga a relação entre a socialização e o conteúdo dos saberes dispensados nas carreiras do ensino profissionalizante na França. Trata-se de uma análise sociológica da experiência escolar, a partir de duas hipóteses: a da consideração do aluno como síntese original de uma história social e a da importância do contexto escolar na construção do sentido dos saberes e da aprendizagem.

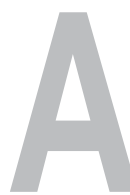

s pesquisas sociológicas sobre o mundo escolar na França são numerosas e variadas, e a profusão de trabalhos e a diversidade das problemáticas levantadas nestes três últimos decênios dão testemunho disso. Se não se pode deixar de assinalar a importância da literatura sociológica relativa ao colégio e ao liceu (cf. Dubet, 1991; Felouzis, 1994; Rayou, 1994; Bautier \& Rochex, 1998), nem por isso deixa de ser verdade que poucos trabalhos se consagraram à experiência escolar nos liceus profissionais. Algumas pesquisas clássicas ou recentes conseguiram, entre-
PALAVRAS-CHAVE ensino profissional, saberes escolares, sujeito aprendiz, contexto escolar, socialização.
Mestre de conferências no Instituto Universitário de formação de mestres, Villeneuve d'Ascq, França e pesquisador da Universidade de Paris 8, Equipe ESCOL 


\footnotetext{
${ }^{1}$ Usamos a expressão "relação com os saberes" no plural para fazer referência aos saberes escolares e profissionais, que os alunos identificam como "matérias". Trata-se, com essa expressão, de ligar estreitamente o discurso dos alunos aos discursos constituídos, que são os saberes ensinados, e de explicar as lógicas sócio-subjetivas em operação na definição e na apreciação das matérias e de suas modalidades de expressão-manifestação.
}

tanto, trabalhar a situação "específica" do ensino profissional. Este é o caso da pesquisa clássica levada a cabo por C. Grignon (1971) sobre as funções sociais do ensino técnico. As pesquisas feitas por L. Tanguy (1991) focalizaram sobretudo a experiência de mudança vivida por operários que se tornaram professores em liceus profissionais. Se essas pesquisas esclarecem o estatuto institucional e "ideológico" do ensino profissional, elas permanecem contudo bastante evasivas a respeito daquilo que os alunos vivem e do modo pelo qual eles se defrontam com os saberes, saberes que possuem a particularidade de serem ao mesmo tempo descontextualizados e profissionais (ou "práticos"). Levadas por uma problemática geral sobre o estatuto do ensino profissional no campo da educação e dos intercâmbios socioeconômicos, a maioria das pesquisas relativas ao ensino profissional centrou-se nas suas finalidades, o que explica a importância atribuída à relação entre a formação e o emprego (cf. Monaco, 1993; Agulhon, 1997).

Dispomos de pouco material sobre a experiência escolar dos alunos do liceu profissional. É certo que algumas pesquisas conseguiram assinalar, aqui e ali, os efeitos gerados por uma escolarização numa "via de rebaixamento" (cf. Dubet, Cousin \& Guillemet, 1991), mas o propósito parece, numa tradição sociológica, mais ligado ao estudo do processo de socialização do que à análise das relações entre a chamada socialização e os saberes. É o que este artigo se propõe a tratar, partindo da experiência dos alunos escolarizados em liceus profissionais em duas carreiras: o CAP (Certificado de Estudos Profissionais) e BEP (Brevê de Estudos Profissionais).

Nosso objetivo se inscreve no quadro de renovação dos paradigmas sociológicos que se deve ao mesmo tempo às mutações sociais em particular o fato da "ruptura da unidade do social" (Dubar, 1991) e da "desinstitucionalização" (Dubet \& Martucelli, 1996) - e à (re)descoberta do sujeito enquanto "síntese original de uma história social" (Charlot, 1999). Se o mundo social implica uma reconstrução e um trabalho de atribuição de sentido (Berger \& Luckman, 1966), entende-se o interesse de uma abordagem sociológica da experiência escolar feita de modo mais próximo possível dos alunos, os aprendizes.

\section{Nas origens de uma interrogação: sobre a inserção dos jovens no liceu profissional}

Duas razões nos conduziram a pensar a experiência escolar e mais particularmente a relação com os saberes ${ }^{1}$ entre os alunos do liceu profissional: as informações de pesquisas anteriores sobre a inserção social e profissional dos jovens (Jellab, 1996; 1997, a, b; 1998) e uma experiência profissional no conselho de orientação dentro de uma escola profissional. Em pesquisas empreendidas sobre a entrada dos jovens na vida ativa, observamos sobretudo nesse público um certo desencanto, em particular no que concerne à distância entre a qualificação (escolar e/ou profissional) e o emprego ou ativi- 
dades exercidas. Aliás, notamos a existência de uma relação crítica com o mercado de trabalho entre os jovens do nível V, e mais particularmente entre o público que tem um nível CAP. Por essa razão, podemos legitimamente nos interrogar sobre o sentido de uma experiência escolar entre os alunos que não pensam estarem destinados a tornar-se "desempregados como os outros" (expressão usada por Cindy, aluna de CAP “empregada técnica de coletividades"). Essas opiniões, ouvidas tantas vezes entre os alunos de liceu profissional, e isto no quadro de nossa experiência profissional como conselheiro de orientação, contribuíram para que eu empreendesse uma pesquisa sobre o sentido da experiência escolar e dos saberes com os quais os alunos se defrontam. Para isto, se nos mantemos no quadro das opiniões dos alunos no momento em que se encontravam com o conselheiro de orientação, era fácil constatar que por detrás das inquietações manifestas - em particular quanto às dificuldades de inserção profissional futura - se perfilavam diversas lógicas que iam da vontade de prosseguir os estudos ao desejo de entrar rapidamente na vida ativa. Mas há igualmente uma certa dificuldade experimentada pelos estudantes em situar os mecanismos do ensino que emergia de suas afirmações, o que leva a pensar pelo menos em não dissociar o discurso dos alunos do contexto escolar e de suas especificidades.

Se nossa experiência no conselho de orientação contribuiu para a problematização da relação com os saberes entre os alunos do liceu profissional, ela também teve parte na adoção de uma outra "postura sociológica", mesmo dependendo mais do domínio da ação do que da pesquisa. À primeira vista, com efeito, se o perfil social dos alunos do liceu profissional ${ }^{2}$ pressupunha uma experiência escolar dominada - mesmo que fosse apenas porque numerosos alunos experimentam a orientação em liceu profissional sob o modo de uma sanção - nada permitia prever uma homogeneidade nas maneiras de viver e de falar da experiência de aprendizes. Indo mais longe, podemos supor que a heterogeneidade das carreiras (CAP e BEP) e das especialidades permite, por si só, considerar que a experiência escolar é proteiforme e não poderia ser reduzida a uma realidade coletiva homogênea, reproduzindo mais ou menos a pertinência social e cultural dos aprendizes. Em outras palavras, e as pesquisas realizadas sobre a inserção dos jovens nos confirmaram isso, a compreensão das trajetórias sociais dos indivíduos não poderia se acomodar às únicas referências aos quadros socializadores anteriores, ao meio social se for o caso, na medida em que a história social de cada um é sempre uma confrontação com universos complexos que influenciam mais do que determinam o futuro (cf. Lahire, 1998).

Nesta perspectiva, a abordagem sociológica da experiência escolar dos alunos do liceu profissional - mas também dos outros alunos - implica um trabalho que parta daquilo que é vivido pelos indivíduos em situação e no caso sua relação com os saberes escolares profissionais. Por isso, uma sociologia da experiência escolar que interprete "em positivo" a escolaridade dos aprendizes - no sentido de que os alunos são sujeitos de início confronta-
${ }^{2} \mathrm{O}$ liceu profissional no qual exercemos o conselho de orientação se situa numa antiga bacia de minério do Pasde-Calais e forma para as especialidades do terciário, em particular para as áreas de cuidados, serviços e restauração rápida. Em seguida, a escolha de levar a pesquisa de campo para outros liceus profissionais permitiu "neutralizar" a ambigüidade introduzida pelo estatuto de "prático-pesquisador". 
Várias pesquisas concordam em sublinhar que os modelos teóricos clássicos em sociologia não são mais suficientemente operacionais para dar conta das trajetórias sociais dos indivíduos. Assim, O. BenoîtGuilbot (1990) propôs uma abordagem qualitativa das trajetórias dos desempregados há muito tempo, interrogando os efeitos de sua "qualificação social" (ou história biográfica). C. NicoleDrancourt (1994) observa que a análise estatística que raciocina em termos de variáveis causais se revela bastante insuficiente para compreender o futuro profissional diversificado dos jovens que possuem sensivelmente os mesmos atributos objetivos. A "sociologia da experiência" proposta por F. Dubet (1994) contribui, por sua vez, para esclarecer a complexidade social situandose com a lógica dos atores que não estão totalmente socializados, nem totalmente livres (o que lhe permite pensar a relação entre o ator e o sistema, sem confundilos). Por essa razão, são os próprios termos da socialização que são redefinidos, já que esta se refere menos a um processo de integração do que a uma interação entre os sujeitos e contextos. dos a conteúdos, atividades e práticas pedagógicas específicas - leva à análise do quadro socioinstitucional no qual os alunos "aprendem". Dois eixos então permitem circunscrever o domínio de uma abordagem sociológica das "formas de relação com os saberes": o da hipótese do aluno como síntese original de uma história social (cf. Charlot, 1997) e o da importância do contexto escolar na construção do sentido conferido aos saberes e ao aprender, no caso, no liceu profissional. A discussão prévia desses dois eixos permitirá traçar o quadro teórico e metodológico que orientou nossa pesquisa empírica.

\section{Uma sociologia da relação subjetiva com os saberes escolares (e profissionais): sobre o estatuto do sujeito aprendiz}

Várias pesquisas se interessaram, recentemente, pelas relações complexas entre os alunos, como sujeitos, e os saberes, como discursos constituídos. Essas pesquisas, pertencendo a várias disciplinas (cf. Charlot, Bautier \& Rochex, 1992; Beillerot, 1996), têm como ponto comum a vontade de dar conta das diferentes carreiras escolares aproximando-as mais das diferenças de relação com o(s) saber(es) do que das diferenças devidas à pertinência sociocultural. Contra uma "sociologia sem sujeito", incarnada pelos trabalhos de Pierre Bourdieu, e de maneira mais nuançada do que a "sociologia da subjetivação" (cf. Dubet, 1991; Dubet \& Martucelli, 1996; Bautier \& Rochex, 1998 e Charlot, 1997 e1999), sustentam que toda experiência da relação com o saber (escolar e/ou social) é elaborada numa relação social e singular, relação intersubjetiva mas também relação com o mundo e consigo mesmo. A relação com os saberes escolares supõe sempre uma construção de sentido: sentido da escola, finalidade dos saberes e relação subjetiva com as atividades desenham os contornos de uma experiência escolar que obriga o aprendiz a uma mobilização de si. Além da contribuição heurística de uma tal concepção - em particular quando se trata de compreender os "casos particulares" de sucesso escolar no meio popular (cf. Terrail, 1990; Laurens, 1992) - ela oferece a possibilidade de pensar a relação concreta com as atividades escolares e a experiência social de cada um.Por meio da questão da apropriação dos saberes, a singularidade da experiência escolar está ligada à hipótese segundo a qual os indivíduos, colocados diante das mesmas situações, confrontados com as mesmas práticas pedagógicas, não efetuam o mesmo trabalho de sentido e finalização dos conteúdos ensinados ${ }^{3}$. É sempre por intermédio da dialética socialização familiar (ou história biográfica) e socialização escolar que a relação com os saberes escolares se torna inteligível: "a elaboração do sentido que cada jovem dá à sua experiência escolar, as modalidades segundo as quais ele aborda e negocia os problemas e momentos decisivos desta não podem então ser pensadas independentemente da história familiar, das continuidades e contradições (inter)subjetivas que se enlaçam no interior dos processos identificatórios ligados às relações entre gerações. Inversamente, a história familiar, os valores e as práticas que a organizaram são, por sua vez, 
sempre testadas pelo futuro das crianças. Estas, quando têm êxito na escola, apropriam-se não somente dos conhecimentos mas também das práticas de linguagem, dos gostos e práticas culturais a partir dos quais não podem deixar de avaliar de volta os de seus pais, sua família, mas também aqueles que não foram os seus" (Charlot, Bautier \& Rochex, 1992, p. 115). Essa relação simbólica entre a história familiar e a escolaridade permite ultrapassar a teoria da herança socio-cultural, que não pode explicar os casos de sucesso no meio popular, na medida em que supõe que a distância entre os diferentes "capitais" (cultural, social, econômico e simbólico) é "reproduzida" pelas diferenças escolares entre as classes dominantes e as classes dominadas.

Por essa razão, partindo do sentido que os aprendizes dão à sua escolaridade e aos saberes, pode-se dar conta das relações entre história sociofamiliar e mobilização subjetiva e estabelecer que as diferenças de carreira escolar se devem a diferenças na relação com os saberes e com o aprender. Esse procedimento permite igualmente a interrogação sobre os saberes e sua finalidade institucional e ideológica e sobre seu efeito formador e transformador do sujeito aprendiz.

Os alunos de LP provêm majoritariamente dos meios populares. À luz de uma abordagem que associa um olhar sobre a biografia dos alunos e uma contextualização das "formas de relação com os saberes" é possível ver como o sentido do aprender, de uma aprendizagem profissional e de uma escolaridade em LP é diferentemente apreciado segundo os fatores objetivos (tais como a carreira, a especialidade, o sexo...) e subjetivos (itinerário escolar, história familiar, relação pensada com o futuro...). Essa perspectiva teórica e empírica permite ultrapassar os estereótipos sociais e "eruditos" ligados ao ensino profissional ("via de exclusão", "via de garagem"...) na medida em que põe em evidência que o "fracasso escolar" não é a realidade de todos os alunos e que por trás da hierarquia das carreiras e das especialidades se perfila uma diversidade das maneiras de viver e de dizer sua experiência de aprendiz.

Os alunos escolarizados em LP se confrontam com saberes e práticas pedagógicas que visam de início torná-los "profissionais" no sentido em que a finalidade maior de sua escolaridade permanece sendo sua preparação para a vida ativa, operária no essencial. Entretanto, os saberes ensinados não se referem apenas aos conteúdos profissionais. Assim, as formas assumidas pelos saberes ensinados incitam a dar conta da especificidade do que é ensinado e, portanto, a considerar que as duas formas dominantes que são a "forma escolar" e a "forma profissional" contribuem para estruturar o sentido da experiência escolar entre os alunos de CAPe de BEP.

\section{Liceu profissional e relação com os saberes: contextualizar a experiência escolar?}

Os saberes ensinados no liceu profissional são, formalmente, distinguidos em termos genéricos de "ensino geral" (ou teórico e 
descontextualizado) e "ensino profissional" (ou tecnológico enquanto preparação, acompanhamento ou explicitação de situações práticas). Essa dualidade de ensinamento e de seu conteúdo define a particularidade do ensino profissional no meio escolar e mostra, de imediato, uma proximidade entre os saberes e a vida profissional. Assim, as transformações sofridas pelo liceu profissional se devem, pelo menos parcialmente, às mudanças que afetam o mercado de trabalho, neste caso, no plano da elevação do nível de qualificação (cf. Pelpel \& Troger, 1993; Bouyx, 1997). Por meio de estágios em empresas, os alunos de liceu profissional se confrontam com práticas que podem ora dar consistência aos saberes ensinados no LP, ora aparecer como distanciados da experiência escolar. Duas formas especificam então os saberes ensinados no LP: a forma escolar que se refere a saberes descontextualizados e afastados de seu uso imediato (cf. Vincent et alii, 1994); a forma profissional que remete a saberes profissionais, supostamente "práticos" e "metodológicos" (ensino tecnológico). Qual pode ser o efeito de um contexto escolar e profissional sobre a maneira pela qual os alunos definem sua relação com os saberes e constroem seu futuro? Pode-se supor que a relação com os saberes é fortemente impregnada pela experiência escolar e considerar portanto que os modos de expressão-transmissão de conteúdos escolares participam do olhar subjetivo dirigido à escola e sobre suas finalidades. O princípio imanente ao LP, ou seja, a distinção entre o ensino geral e o ensino profissional, constitui um motivo de debate tanto em relação à legitimidade dos saberes oferecidos (qual é a legitimidade, na opinião dos alunos, do ensino geral em relação à aprendizagem de uma profissão?) quanto em relação à questão de sua articulação.

Os alunos de liceu profissional freqüentemente tiveram a experiência de uma carreira e/ou uma determinada especialidade não escolhida (cf. Agulhon, 1994). Entretanto, se não se pode fazer abstração desta coação institucional e de seus possíveis efeitos sobre a mobilização do aluno, também não se pode subscrever a uma relação mecânica entre a orientação recebida e uma relação crítica (ou "descomprometida") no que concerne aos saberes ensinados. Trabalhar a questão da relação com os saberes assim como a da relação com a socialização profissional no liceu profissional supõe levar em conta as razões da entrada nessa instituição (em particular se se trata de compreender como o aluno se orientou, se ele "escolheu" ou "foi levado a escolher" essa orientação...) e a análise das relações concretas (subjetivas) construídas com os saberes ensinados e, de um modo geral, com o liceu profissional. Essa perspectiva, que alia a trajetória sócio-escolar e familiar do aluno e o contexto de escolarização, tenta ultrapassar a oposição arbitrária entre socialização e aprendizagem, já que ela supõe sua imbricação (quanto a este aspecto, as pesquisas recentes em sociologia da educação são inovadoras, visto que não são focalizadas somente na socialização). Por essa razão, quando o aluno constrói uma relação com os saberes, isto é efetuado num universo de relações específicas intra e extraescolares, que vão das relações com os professores, com os colegas, as relações intrafamiliares, passando pela socia- 
bilidade com os pares (amigos, colegas da cidade...).

Como o campo do LP tem essa particularidade de "produzir" uma socialização profissional, ele leva a supor que as aprendizagens que os alunos aí realizam são de uma ordem específica: se o aluno adquire saberes, mas também um savoir-faire, relacionado a uma profissionalização e identificado ao "fazer" porque o aluno é levado a aprender uma "cultura profissional" (Tanguy, 1991), não se pode pensar sua experiência tão somente sob o ângulo da socialização por meio da confrontação com os saberes descontextualizados. A relação com os saberes é parcialmente tributária das atividades e dos ensinos oferecidos e sobretudo da maneira pela qual os saberes profissionais participam de sua socialização ${ }^{4}$.

Variáveis qualitativas são obtidas do nosso público e do contexto escolar que é o LP. Isto acontece com a carreira: os alunos de BEP vêm, em sua maioria, do colégio. Freqüentemente experimentam uma carreira e uma especialidade que não escolheram. Quando a escolha é percebida como tal, trata-se o mais das vezes de uma orientação "por falta" ("não ter podido ir para um liceu geral"). O BEP apresenta a particularidade de ser ao mesmo tempo um diploma profissional e um primeiro nível de qualificação que leva ao bacharelado profissional ou tecnológico. Assim, os alunos de BEP têm, objetivamente, mais chances de viver sua experiência escolar como um "novo início". Os alunos escolarizados em CAP (exceto alguns CAP "elitistas" que não constituem nosso público) provêm de seções de ensino especializadas (SES, hoje em dia chamadas SEGPA), e às vezes de dispositivos especiais tais como as terceiras séries de inserção e as "formações qualificantes" (trata-se de alunos escolarizados, na origem, em SES e mantidos durante um ano após a terceira série num quadro escolar balizado no cumprimento de estágios em empresas. As perspectivas escolares dos alunos de CAP são reduzidas no final de sua formação. Formados para exercer uma atividade profissional especializada, esses alunos constituem um público cuja escolaridade é identificada com um "fracasso"; eles pertencem à categoria dos $20 \%$ dos alunos que saem do sistema escolar com uma qualificação nível V. Por essa razão, pode-se supor que existiria uma relação entre o campo das possibilidades oferecidas pela obtenção de um diploma (no caso o CAP e o BEP) e a relação com os saberes escolares e profissionais.

A carreira escolar não é a única que teria parte no sentido conferido aos saberes. A especialidade contribuiria, por sua vez, para estruturar o universo perceptivo dos aprendizes já que ela se apóia sobre atividades específicas. As atividades solicitam os alunos de maneira variável. Se os ensinamentos teóricos são globalmente idênticos entre um BEP e outro ou um CAP (entre o BEP e o CAP os conteúdos teóricos diferem no sentido em que são mais variados, mais densos e mais descontextualizados no quadro do primeiro diploma), é no plano do ensino profissional que residem as diferenças: porque, tratando-se de atividades profissionais consideradas pertencentes a um campo profissional mais ou menos definido, esse ensino põe o aluno dian-
${ }^{4}$ As pesquisas que devemos a Claude Dubar assinalam que a socialização é um processo contínuo por meio do qual os indivíduos "negociam" sua relação com as instituições apropriando-se dos saberes que não deixam de trazer uma modificação de sua visão do mundo e de si mesmos (de sua identidade) assim como das estratégias que desenvolvem. "É pela análise dos "mundos" construídos mentalmente pelos indivíduos, a partir de sua experiência social, que o sociólogo pode construir melhor as identidades típicas pertinentes num campo social específico. Estas "representações ativas" estruturam os discursos dos indivíduos sobre suas práticas sociais "especializadas", graças ao domínio de um vocabulário, à interiorização de "receitas", à incorporação de um "programa", em suma, à aquisição de um saber legítimo que permita ao mesmo tempo a elaboração de "estratégias práticas" e a afirmação de uma "identidade reconhecida" (cf. Dubar, 1991, p. 105). 
te daquilo que define a própria identidade de sua formação e, portanto, contribui para estruturar sua relação com o mundo e consigo mesmo, o que participaria do próprio sentido conferido ao aprender (fabricar cabos ou limpar locais pertencem a atividades social e subjetivamente portadoras de sentido, de modo que a identidade do aluno pode ser estreitamente delimitada através da identidade da formação).

Uma problemática sociológica da relação com os saberes entre os alunos de LP supõe a existência de uma incidência contextual sobre o sentido que é conferido ao seu estatuto de aluno e de aprendiz. Mas o aluno, posto como sujeito, é portador de uma história que atravessa sua experiência escolar, ao mesmo tempo em que é produzida parcialmente por esta. Assim, o sentido conferido aos saberes não pode ser inteligível a não ser que se leve em conta o contexto da escolarização e da história - mais do que da trajetória - do aluno, uma história compósita na qual as socializações familiar e escolar anteriores ocupam um lugar princeps. É assim que optamos por entrevistas do tipo biográfico, feitas com alunos no interior de liceus profissionais, a fim de destacar o sentido conferido aos saberes e às aprendizagens.

\section{Uma pesquisa sociológica em quatro liceus profissionais}

Se postulamos que a experiência escolar assim como toda experiência social implicam relações complexas entre o indivíduo e o contexto, que elas obrigam os sujeitos a um trabalho de elaboração de sentido e de "transação" entre eu e o outro, podemos considerar que esse sentido variaria segundo os contextos com os quais os indivíduos são confrontados, mas igualmente segundo a socialização anterior - ou a história biográfica - de cada um. É a partir desses princípios preliminares, onde se tratava ao mesmo tempo de circunscrever o contexto (aqui, o LP) com o qual o aluno é confrontado e o público (a socialização objetiva e subjetiva anterior variada), que definimos o terreno da pesquisa. A escolha do público - alunos de CAP e de BEP - colocava de imediato a existência de diferenças quanto à trajetória escolar anterior: os alunos de BEP provêm de classes de terceira série geral ou tecnológica. Eles conheceram uma "ruptura" quase sempre dolorosa no final de sua escolaridade no colégio, visto que, o mais freqüentemente, dizem ter sido "orientados" para irem para o LP, numa especialidade não desejada. Os alunos do CAP vêm, por sua vez, do ensino especializado ou adaptado (terceira SES, terceira de inserção; pelo menos esse é o caso da maioria dos alunos do CAP junto aos quais fizemos a pesquisa de campo). Sua escolaridade é fortemente associada, do ponto de vista institucional, à hipótese da "deficiência intelectual”. As diferenças ligadas à carreira se conjugam com aquelas ligadas à especialidade. Foi assim que escolhemos o liceus profissionais cujas formações eram variadas tanto no nível das carreiras quanto das especialidades. Quatro liceus profissionais de tamanho e formações contrastadas, situados no Pasde-Calais, constituíram o campo de nossa pesquisa. Dois liceus formam para 
as especialidades industriais (eletrotécnica, mecânica, automóveis, manutenção de sistemas mecânicos, estruturas metálicas, marcenaria...), e acolhem aproximadamente 600 alunos cada um. Os outros dois liceus preparam para as especialidades do setor terciário (venda, secretariado, costura, bioserviços, manutenção de locais, carreiras sanitárias e sociais). Esses dois liceus acolhem, cada um, mais ou menos 500 alunos. Nos quatro liceus profissionais, encontramos alunos que vieram do ensino especializado e preparam pois para os CAPs que "recrutam no essencial nas terceiras séries SEGPAe nas terceiras séries de inserção" (documento oficial do Reitorado de Lille).

Para recolher material suficientemente significativo para nossa pesquisa, encontramo-nos com alunos do primeiro e segundo anos de CAP e de BEP. As entrevistas decorreram nos liceus e partiam explicitamente de uma questão centrada na escola. "Pode me dizer o que pensa ter aprendido na escola desde que é aluno?" era a questão inicial. Às vezes podíamos, segundo as circunstâncias, iniciar a conversa convidando o aluno a contar seu percurso escolar anterior. A questão inicial visava em primeiro lugar situar o sentido que o aluno dava ao fato de ir à escola e as aprendizagens que ele julgava efetuar. Queríamos igualmente captar o impacto de sua experiência atual sobre o sentido conferido à escola e aos saberes. Na medida em que uma problemática da relação com os saberes implica prestar atenção aos conteúdos escolares, tentamos levar os alunos a nos falar das matérias, situações em que pensam aprender e, eventualmente, de mudanças que pensam ter vivido na experiência no LP. Partindo do postulado segundo o qual a experiência escolar é sempre experiência singular de um sujeito que aprende, portador de uma história escolar e familiar, que ela dá lugar a recomposições e transformações da relação com os saberes e que ela não poderia ser apreendida independentemente dos contextos de socialização com os quais o indivíduo se defronta, a entrevista biográfica da pesquisa parecia nos oferecer a possibilidade de pensar qualitativamente a relação complexa entre o aprendiz e os saberes ensinados. Se a abordagem biográfica permite ir além das controvérsias relativas à oposição entre o sujeito e a sociedade (cf. Demazière \& Dubar, 1997), ela não se avalia como discurso subjetivo e introspectivo sobre si. A biografia é sempre um fragmento de uma história subjetiva atravessada por relações sociais e intersubjetivas que lhe dão consistência ${ }^{5}$. Nesse sentido, os alunos que são levados a falar conosco sobre sua história sócio-subjetiva e de sua trajetória escolar podiam alternadamente lembrar sua relação com os outros (família, professores, colegas), objetos socialmente situados (matérias escolares, diversão, obrigações domésticas...) e, portanto, fornecer à análise elementos que podiam "explicar" as formas de relação com os saberes.

No total, foram feitas 40 entrevistas, em diferentes LP. Seu desenvolvimento se baseava na leitura de entrevistas precedentes, efetuadas com outros interlocutores. Assim, os pontos sobre os quais insistíamos podiam variar na medida em que transcorria a pesquisa. Nessa perspectiva, a escuta do aluno podia encontrar eco em biografias e percepções de outros alunos,
5 A abordagem biográfica, herdada historicamente das pesquisas levadas a cabo pela Escola de Chicago (cf. Grafmeier \& Joseph, 1979) e formalizada por Glaser e Strauss (cf. Demazière \& Dubar, 1997) é de uso recente em sociologia da educação. Ela parece ganhar mais interesse quando as interrogações giram em torno do sentido que os sujeitos dão à sua experiência, um sentido estreitamente ligado às formas de mobilização postas em ação face a contextos diversos. Por essa razão, os alcances heurísticos da entrevista são redefinidos, em particular no que diz respeito ao interesse pelas "histórias singulares" em relação ao procedimento totalizante em sociologia. As referências metodológicas relativas à entrevista são numerosas (cf. Bertaux, 1997). Nós nos situamos numa perspectiva sociológica que considera que o campo é menos um quadro que permite a confirmação de hipóteses preliminares do que um contexto produtor de materiais que podem gerar um olhar transformador da perspectiva teórica adotada preliminarmente. O campo é então abertura para o inédito. É por isso que a relação com os alunos se pretende "compreensiva", o que supõe ao mesmo tempo uma escuta atenta, que dá liberdade ao interlocutor, e intervenções que visam levar a narração na direção da explicação do sentido. 
sem que a singularidade e regularidade da experiência escolar se confundissem.

Na medida em que privilegiamos uma abordagem qualitativa, tivemos cuidado sobretudo para que nossos interlocutores fossem "significativos" (cf. Michelat, 1975) do "tipo" de alunos escolarizados habitualmente em LP. A questão era menos dar conta de "toda" a experiência da relação com os saberes entre os alunos de LP do que extrair as linhas de análise que permitissem "ler" o que pertencia à experiência de uma relação complexa entre a biografia e o sentido dos saberes.

\section{Contexto escolar e produção de sentido: sobre a relação entre aprendizagem e socialização.}

A análise das entrevistas permite ver de que modo a relação com os saberes e o sentido do aprender são apreciados por meio da junção entre história individual (social e escolar) e o contexto de escolarização que, pela existência de duas formas e por sua "abertura" para o mundo do trabalho (especialmente por causa dos estágios), leva os sujeitos a uma constante tarefa de reconstrução e de busca de coerência. Se não se pode definir objetivamente a parte assumida pela socialização familiar nas formas de mobilização da escola (cf. Bautier \& Rochex, 1997), a trajetória escolar de cada aluno mostra que esses dois universos - família e escola - estão em constante "diálogo" na medida em que a apropriação do saber põe o aprendiz diante de escolhas emancipatórias ou reprodutoras (mas nunca idênticas) de seu hábito social.

Tudo se passa como se o sentido do aprender e as finalidades de uma aprendizagem escolar fossem identificadas à "preparação para a profissão" e à entrada na vida ativa. Ao mesmo tempo, alguns alunos revelam a importância de uma apropriação dos saberes em relação à sua dimensão formadora. Essas diferenças que, a priori, exprimem os efeitos ligados à especificidade da forma escolar do LP, são avaliadas a partir de dois eixos principais:

- o do efeito - contexto sobre o sentido conferido aos saberes. De fato, o discurso sobre a escola procede amplamente da posição ocupada atualmente no contexto e na organização escolares;

- o da história sócio-subjetiva que, no interior de um público objetivamente homogêneo, dá conta das variações quanto ao sentido conferido à escola e às formas de mobilização sobre os saberes.

Assim, a entrevista com os alunos permite avaliar as relações complexas entre a escolaridade em LP, a relação com os saberes e as maneiras de falar e viver sua experiência de aprendiz.

Pesquisas anteriores (cf. Charlot, Bautier \& Rochex, 1992; Beillerot, 1996) mostraram a importância da relação com o outro na construção do sentido conferido aos saberes. Essa realidade, que pensa o sujeito apren- 
diz por intermédio dos modos de relações subjetivas e sociais, é tangível entre os alunos. Contudo, a relação com o outro como dimensão simbólica e identitária não implica nem nos mesmos modos de relação nem nas mesmas formas de mobilização subjetiva. Assim, quando os alunos dizem "trabalhar para que o professor o veja", ou "ter êxito na escola porque sei que minha mãe está preocupada com meu futuro", concebe-se que a expressão genérica "relação com o outro" convida a um esclarecimento nuançado. Três dimensões essenciais definem as relações intersubjetivas e simbólicas que participam da experiência do aprender entre os alunos de CAP e de BEP: a relação com os professores, com seus pares (inclusive os amigos próximos) e com a família.

\section{A relação com os professores}

A narração de sua história e de sua relação com o LP abrange, de modo recorrente, a relação com os professores e sobretudo com o olhar que estes exprimiriam relativamente aos alunos, levados por seu estatuto de dominantes. Assim, "a maneira pela qual nos tratam", assim como "o professor que sabe nos ouvir" participam dessa experiência da relação pedagógica, na qual os saberes ganham sentido através das modalidades com as quais os alunos constroem interativamente sua relação com o professor. Os professores são investidos de um poder pluridimensional: "eles ensinam as lições”. "encorajam os alunos", "ajudam a compreender melhor". "sabem nos ouvir"... Se os alunos de CAP superestimam mais do que os de BEP o poder dos professores, estes últimos parecem viver de modo diferente essa experiência segundo a especialidade e o sexo. As moças dão uma importância mais "pedagógica" aos professores, destacando sua aptidão para ensinar, para explicar e a usar o tempo para ditar; enquanto que os rapazes assinalam mais o caráter "pessoal" do professor evocando seu "espírito cool", o fato dele tratar os alunos "como se fossem adultos" e que não "lhes esquenta a cabeça com a escola". A especialidade aparece também como discriminante na medida em que, nas formações industriais, a importância dada a uma forma profissional participa de modo relacional e afetivo com o professor, enquanto lá onde predomina a forma escolar (nas especialidades do setor terciário) as competências pedagógicas são mais valorizadas na relação. O peso das especialidades pode ser finamente avaliado no interior de um mesmo setor: assim, os alunos do BEP “eletrotécnico" não subscrevem apenas à forma profissional, mesmo se podem valorizar o professor que explica dando exemplos práticos. Do próprio fato das matérias profissionais serem, em grande parte, dispensadas sob a forma de cursos teóricos, os professores são bastante próximos dos alunos no setor terciário, privilegiando a explicação na relação compreensiva entre professor e aluno.

Os alunos do LP conferem ao professor um papel ativo na relação de aprendizagem. Contudo, oscilam entre duas visões do "bom professor": uma visão escolar, mais voltada para a capacidade para "fazer os alunos 
compreenderem" as lições e o curso. Essa visão está presente sobretudo entre os alunos do BEP, em particular nas especialidades do setor terciário ( o que explica que a encontremos sobretudo entre as moças, que são maioria nessas especialidades). A outra visão é mais voltada para a "atitude de escuta que o professor deve ter quando temos problemas ou que se quer falar de outra coisa que nos interessa", dirá Frederic, 17 anos, aluno de CAP "construção de conjuntos de caldeiraria". Encontra-se essa lógica centrada sobre fatores de ambiente entre os alunos em especialidades industriais (em sua maioria masculinas), e, de maneira mais decisiva, entre o público dos CAP. Por essa razão, a predominância de uma lógica relacional sobre uma lógica sociocognitiva (ou pedagógica, aliando os saberes, o professor e o aluno) explica porque os alunos definem as aprendizagens escolares e profissionais apenas sob o ângulo "socializador". Kevin, 18 anos, aluno de CAP "marcenaria- gerenciamento", exprime, nestes termos, o que ele julga aprender no LP e a relação com os professores: “... aqui, aprendo sobretudo a ouvir os outros, vejo um pouco o que nos mandam fazer e discuto com os professores... é bem o LP, gosto do atelier porque o professor não fica atrás de mim... os professores, eles são simpáticos porque se pode falar com eles sobre tudo e brincar um pouco". Globalmente, os alunos do BEP dão testemunho de uma autonomia relativa em relação aos professores, afirmando parcialmente que a aprendizagem depende de sua mobilização sobre os saberes e da "motivação para ir mais longe". Os alunos do CAP mostram uma forte dependência em relação aos professores de modo que os casos de êxito ou fracasso escolares permanecem associados à eficácia do professor.

\section{As relações entre a família e a escola}

Se o contexto escolar contribui para a elaboração de um sentido específico para a escola e os saberes, as entrevistas biográficas explicam o fato de que a interação entre o aluno e a escola seja sempre atravessada pelo peso das relações simbólicas construídas no interior do meio familiar (cf. Lahire, 1995). Por meio dessa abordagem da experiência sociofamiliar dos alunos de LP, o que se manifesta é que as formas de mobilização, as dúvidas e as ambivalências a respeito da instituição escolar são apreciadas à luz das relações complexas entre o aprendiz e a família. A experiência escolar dos alunos é estreitamente ligada à experiência sociorrelacional e afetiva na família. Se estamos aqui diante de uma constatação banal, isso implica entretanto uma nova concepção da relação com a família, na medida em que, escolarizados numa instituição que faz a apologia da "responsabilidade" e que profissionaliza os alunos, que devem tornar-se "adultos", os sujeitos vivem sua relação com o LP sob a forma de uma transição identitária que incide sobre as relações construídas com o universo familiar, sendo ao mesmo tempo o seu produto. A relação com a família é freqüentemente evocada sob o ângulo daquilo que pode mobilizar os saberes ("aprender para fazer estudos que nossos pais não 
puderam fazer", diz um aluno de BEP “profissões da contabilidade"), da falta de correspondência existente entre a socialização familiar e a socialização escolar ("No colégio, diz Armand, aprendi tudo o que se deve aprender, não posso dizer o que exatamente, e, além disso, é duro, porque os pais não podem ficar atrás de nós, começamos a aprender tudo o que é novo, os pais não conseguem acompanhar porque faz vinte anos que deixaram a escola") e daquilo que inscreve o aluno numa relação contraditória com o mundo escolar (Helène, aluna de CAP “indústria e malhas e roupas" dirá: "Minha mãe me diz que posso vencer se me esforçar [...] mas ela tem razão, minha mãe, quando diz que sou limitada, que não sou inteligente"). Diferentemente dos alunos do colégio, a respeito dos quais a pesquisa revelou que pensam uma estreita dependência entre a escola a família, parece que essa relação admite uma outra significação entre o público de LP. A concomitância entre "crescer" e "se profissionalizar" contribui para o advento de um novo olhar sobre seu estatuto de aluno, criança e futuro operário. Os alunos de CAP, mais do que os de $\mathrm{BEP}$, exprimem uma forte dependência afetiva e relacional para com a família na qual vêem um apoio e um modelo que devem "reproduzir".

Contudo, se os alunos de LP provêm majoritariamente do meio popular, se a profissão mais dominante dos pais é a de "operário" (em atividade ou procurando emprego), parece arriscado pensar sua experiência apenas sob o ângulo de uma "trajetória de reprodução" da classe a que pertencem. Em primeiro lugar porque o LP sofreu mudanças, o que contribui para a modificação das aspirações dos alunos, levados a prosseguir seus estudos. Em seguida, numerosos alunos fazem a experiência de um encontro com saberes novos, em todo caso diferentes daqueles que os pais puderam "aprender" (o que explica o discurso do aluno que dizia que "os pais não conseguem acompanhar"). A experiência dos aprendizes nãoé avaliada fora das relações com o outro, dos quadros e referências identificatórias que lhe dão consistência, legitimidade e sentido. Esse outro é múltiplo: pode se tratar dos professores ou dos pais; pode também ser questão dos colegas ou do grupo de pares. $\mathrm{Na}$ verdade, esses diferentes atores agem como relações complexas e como processos, de sorte que a relação com os saberes é atravessada pela interação entre essas diferentes relações. Mas pode-se facilmente supor que a natureza dessas diferentes relações varia segundo se trate da família, dos professores ou dos grupos de pares. A sociabilidade adolescente é apreciada em dois níveis: o dos colegas de LP e o dos "amigos de todo dia".

\section{Entre os colegas da classe e os amigos de todos os dias}

As pesquisas sociológicas que se voltam para o sistema escolar e seus atores privilegiaram a problemática da socialização no interior da escola e fora dela, mas elas parecem ter focalizado a atenção mais sobre as relações que engajam os atores (os alunos entre si, os alunos e os professores ou profissionais da educação) do que sobre as relações que se articulam em torno 
${ }^{6}$ Ver, a esse respeito, a leitura crítica que é proposta por Elisabeth Bautier e Jean-Yves Rochex na primeira parte de seu livro (1998). Aí, eles tratam dos trabalhos de François Dubet (1991), de Robert Ballion (1993), de Patrick Rayou (1994) e de Anne Barrèrre (1997).

Muitos são os alunos que evocam a "pressão dos outros" para justificar (ou explicar) as razões de uma apropriação difícil dos saberes assim como de sua assimilação (o que pode ser atestado por uma "boa nota" nos deveres ou nos exames). Entretanto, todos os alunos não vêem nisto um obstáculo insuperável. Alguns alunos, ao mesmo tempo em que denunciam o ambiente ruim da classe e a crítica dos colegas ("somos uns palhaços", "intelectuais". "filhos de papai"...), mobilizam-se acerca dos saberes manifestando uma atenção aos cursos e contornando as formas de controle juvenil dominantes (é o caso de alguns alunos que dizem que "vão falar com o professor no fim da aula, ou, às vezes, nos corredores, para pedir que explique coisas que eu já compreendi", anuncia Jean-Marie). da trilogia sociabilidade-saberes-subjetividades ${ }^{6}$. Nas entrevistas com os alunos de CAP e de BEP, percebe-se, em filigrana ou de maneira explícita, a importância das relações com os colegas e com os amigos na constituição e transformação do sujeito aprendiz.

Entre os rapazes, a sociabilidade juvenil é entendida como autônoma em relação às aprendizagens. Eles são mais sensíveis do que as moças à "aprendizagem para a vida", que crêem efetuar no contato com os amigos fora do LP. As moças são mais atentas à sociabilidade no LP, e em particular no interior da classe: elas são mais numerosas do que os rapazes ao evocar "o bom ambiente", ou o "ambiente ruim da classe para trabalhar". Tudo se passa como se ali onde os rapazes valorizavam as relações entre o mestre e o aluno para "compreender o curso", as moças investiam nas relações de sociabilidade que as engajavam com outros colegas da classe para se mobilizar no que diz respeito aos saberes. Assim, não se pode dissociar a experiência da relação com os saberes escolares da relação com o outro, remetendo nesse caso aos pares. Os alunos dizem que aprendem na classe "porque se vê como os outros trabalham, quando um aluno vai ao quadro, tento ver como ele reflete e se eu acertei o exercício", sugere Adrien, 17 anos, aluno de primeira série de BEP "manutenção de sistemas mecânicos automatizados". Por essa razão, e apesar da idéia dominante segundo a qual "só se escreve na classe", na verdade a experiência do aprender associa fortemente a relação com o outro até no sentido conferido à própria atividade. Assim, Yohann, 18 anos, aluno de segunda série de CAP “construção de conjuntos de caldeiraria”, afirma: "Com o professor de desenho, nós nos perguntamos o que é que ele quer com seus cursos, não se entende nada e com os outros alunos discutimos com o professor para que ela faça outra coisa ou então que explique".

Os alunos de LP são atentos ao seu ambiente relacional imediato, o dos professores, mas também o do grupo de pares. Tudo se passa como se a escolaridade no LP definisse o campo do possível para o aluno e lhe indicasse de maneira informal até onde ele poderia se mobilizar acerca dos saberes. Escutando Christelle, 18 anos, escolarizada em segunda série de BEP "materiais flexíveis", percebe-se importância das relações com os pares no sentido e portanto nas maneiras de engajar sua subjetividade na experiência do aprender: "Nossa classe é perturbada, diz Christelle.... Eles não param de se fazer de palhaços, de saltimbancos, eu sou obrigada a fazer o mesmo que eles, senão vão dizer que sou careta, sei que não está certo, mas não quero ser visto como 'intelectual"'?

Pensar a experiência dos aprendizes independentemente das relações de sociabilidade intra-escolares levaria a cair num impasse sobre os efeitos ligados ao contexto de escolarização sobre as formas da relação aos saberes. Esse contexto não se refere aqui à instituição como estabelecimento no qual o futuro dos alunos é avaliado segundo as políticas e as estratégias educativas de profissionais da educação (cf. Duru-Bellat \& Mingat, 1988). Atribuímos ao contexto escolar uma acepção mais qualitativa, considerada 
tanto do ponto de vista dos elementos objetivos que definem as formações (a especialidade, a carreira...) quanto das relações de sociabilidade que são pensadas de modo indissociável com as aprendizagens escolares e profissionais.

Essas relações de sociabilidade construídas no LP - mas também fora dele - definem as modalidades de implicação com o trabalho escolar e podem orientar as formas de mobilização em relação aos saberes. Por essa razão, quando os alunos evocam "a classe", os "colegas do liceu", eles dão conta das provas subjetivas que experimentam nesse duplo contato com os saberes e com os colegas. Assim, pode-se compreender porque alguns alunos são tomados por uma espécie de desânimo e se defrontam com impasses, sobretudo quando se sentem "ultrapassados" por seus colegas de classe. Severine, 18 anos, aluna de primeira série de CAP "indústrias de malhas e roupas", diz, nesses termos, porque ela tem dificuldade para "compreender os cursos": "...há meninas da minha classe que me deixam de lado, só falam entre si, e todo mundo me deixa de lado, na classe, fico lá no fundo, eu então faço igual... No início, me aceitaram, mas lá, não sei não, é como se eu não existisse... elas falam comigo, me dizem bom-dia, e depois, mais nada”. Essa aluna voltará regularmente aos relatos de sociabilidade para fazer dela um determinante de seu mal estar em "estar lá" e assinalar os seus efeitos sobre as aprendizagens escolares e profissionais. Ela prossegue mais adiante: "Acho que sou sempre a última da classe, sou nula, ora, é verdade, e, no entanto, no início do ano, fazia minhas almofadas e vestidos entre os primeiros, é normal, já que venho de SES, mas aqui, todo mundo está na minha frente, então, é terrível".

A relação com os colegas de classe (e, de um modo mais geral, do liceu) contribui para a percepção que o aluno constrói a propósito dos próprios saberes e de si mesmo. Ao lado da sociabilidade intra-escolar se constrói de uma outra forma de sociabilidade juvenil. Trata-se do conjunto de relações sócio-subjetivas que definem o universo relacional do aluno fora do meio familiar.

A experiência escolar dos alunos de LP é, em primeiro lugar, uma experiência social. Ela procede de uma socialização e de uma história familiar, de uma trajetória escolar anterior e das relações sincrônicas estabelecidas com o LP, com os colegas de classe e amigos da cidade ou do bairro. É por meio dessas relações complexas que definem os modos de socialização que toma consistência a hipótese segundo a qual toda relação com os saberes é ao mesmo tempo e dialeticamente uma relação com o outro e consigo mesmo.

O caso de Benedicte, 16 anos, escolarizada na segunda série de BEP "bioserviços" é instrutivo a esse respeito. Essa aluna, "orientada numa formação" que não escolheu, conta ter ficado "revoltada" com "o BEP onde se aprendem coisas que não servem para nada" (de fato, que não se inscrevem em seu projeto profissional, a saber, tornar-se trabalhadora) e não ter "prestado para nada a primeira série de BEP”. Interrogada sobre as razões de uma metamorfose quanto ao trabalho escolar e à mobilização acerca dos saberes 
durante a segunda série de BEP, ela verá seus resultados melhorarem de maneira significativa, o que lhe permitirá ulteriormente integrar-se numa primeira adaptação "ciências médico-sociais". Benedicte dirá que "compreendeu que sempre só se trabalha por si mesma e por seu futuro". Na realidade, o desejo de aprender, querer ter êxito em matemática, gostar da microbiologia... designam uma dinâmica cognitiva e afetiva que é revelada pela entrevista biográfica. É por meio do conhecimento de um "amigo, do primeiro ano da universidade, que diz que posso vencer", que toma sentido uma mobilização "repentina" em relação à escola e aos saberes.

Uma sociologia das formas de relação com os saberes supõe dois postulados dominantes: o da existência de um sujeito portador de uma história social para cuja construção ele contribui a cada etapa de seu percurso escolar; o de uma imbricação entre a experiência escolar, como mundo de relações sociais e simbólicas, e os conteúdos escolares com finalidade mais ou menos definida, mas obrigando sempre o aprendiz a tomar uma posição (conforme ou não às expectativas institucionais). Por essa razão, a experiência dos alunos de LPé aqui considerada sob o ângulo das relações complexas vividas pelo aprendiz, do contexto escolar e dos saberes ensinados. Se os alunos evocam "as matérias que são aprendidas", os "estágios que são mais verdadeiros do que o LP", "a classe onde a gente só escreve", essas considerações põem em relevo a dificuldade que os aprendizes experimentam para dar sentido (direção e significação) aos saberes, tanto mais que esses saberes pertencem a duas formas: a forma escolar e a forma profissional. Saberes escolares e saberes profissionais (essa distinção permanece pouco pertinente sociologicamente mas admite uma significação muito forte entre os alunos e os professores) prefiguram relações subjetivas variáveis de um aluno a outro, submetidos ao mesmo tempo ao peso da carreira e da especialidade. Assim, se todos os alunos assinalam, globalmente, que "no LP, se aprende uma profissão", nem todos conferem à profissionalização uma acepção positiva e, em todo caso, não identificam sua subjetividade e seu estatuto profissional futuros às atividades profissionais do momento.

\section{Entre aprender uma profissão e aprender na classe: coerência e desvio na experiência escolar}

A escola e o LP são fortemente identificados aos saberes, a conhecimentos que se considera que devem ser "aprendidos" por um público que descobre "novas coisas". Mas os alunos de CAP e de BEP remetem, de maneira recorrente, os saberes constituídos à suas figuras e usos normativos: aprender a ler e saber escrever e contar definem prioritariamente o que se pensa ter aprendido na escola; ao mesmo tempo, essas aprendizagens serviriam sobretudo "para o trabalho que se vai fazer mais tarde". É a predominância de uma forma prática que qualifica, globalmente, as maneiras de viver e de falar sobre sua experiência de aluno de liceu profissional. "No colégio, tem-se 
as bases, aqui, se vai mais longe e se põem as idéias em prática", diz Logan, aluno de BEP "estruturas metálicas". Para Miriam, "na escola, aprendi a cozinhar e passar". Escolarizada em CAP “empregado técnico de coletividades", Miriam não evoca os ensinamentos anteriores no LP, nem a aprendizagem teórica. Mas as figuras do aprender definem as diferentes formas de mobilização e de implicação subjetivas. As formas que nós evocamos aqui valem por seu caráter significativo e "falante" e permitem avaliar melhor as relações complexas entre os saberes e os sujeitos que aprendem.

a) Aprender é "trabalhar com suas mãos": uma forma oral-prática de relação com os saberes?

Aline, de 17 anos, aluna de primeira série de BEP "bioserviços" assim define os saberes: "aprender é aprender a ler, a memorizar... aqui, aprendo a manter locais... e as matérias que se aprendem são matérias práticas". A relação com os saberes remete, em primeiro lugar, à finalidade de um título de formação: aprender a prática, dominar os saberes profissionais. A maior parte dos alunos de LP identificam a aprendizagem com a aquisição de novos saberes sobretudo práticos. $\mathrm{O}$ atelier, a prática e, mais tarde, os estágios em empresas contribuem para a constituição de uma relação "nova" com o mundo escolar. Aliás, aprender evoca "aprendizagem de uma profissão". Assim, Liliane, aluna de CAP "café-brasseria" nos disse, em sua chegada ao LP, que pensava que, "para aprender, era preciso encontrar um mestre de empresa para formá-la durante o estágio". Mas aprender se assemelha também àquilo que "interessa" o aluno, de modo que a preferência pela prática no atelier pode ser interpretada duplamente: de um lado, ela pode manifestar uma relação refratária com a forma escolar naquilo que tem de constrangedor e naquilo que ela evoca como lembranças dolorosas; ela pode exprimir uma relação identitária através da qual o aprendiz associa seu presente de aluno com um futuro profissional (aprender no atelier é então impregnar-se de conhecimentos que servem para a prática, o que pode conduzir à crítica dos conteúdos escolares dexcontextualizados. Para Bruno, aluno de primeira série de BEP "eletrotécnica", "a história, isto não serve para nada para o trabalho que se vai fazer"). Por essa razão, predomina entre os alunos uma forte dissociação entre os saberes teóricos e os saberes profissionais, dissociação que eles tentam superar seja valorizando a prática, seja selecionando nas diferentes matérias aquelas que lhes parecem "interessantes" (em relação aos projetos variados tais como a entrada na vida ativa, o prosseguimento dos estudos...). Devese assinalar que o discurso sobre a prática, sobre o que é manual é fortemente ligado ao contexto de escolarização: um aluno tem tanto mais chances de evocar aprendizagens profissionais quanto mais 1- é escolarizado em LP e 2associa seu futuro a uma entrada próxima no mercado de trabalho.

b) Aprender é descobrir que se é capaz de vencer: sobre a (re)descoberta da forma escolar. 
Como foi lembrado acima, a maioria dos alunos experimentaram dificuldades escolares no colégio e vivem sua entrada no LP sob o modo de uma "orientação pelo fracasso". Essa experiência do constrangimento escolar pode dar lugar a diversas formas de relação com a escola e com os sabres ensinados. Assim, alguns alunos expressam seu desejo de "mudar de orientação no final do ano porque, francamente, não se faz nada de interessante", anuncia Cédric, de 17 anos, aluno de primeira série de CAP "metalurgia". Entretanto, para outros alunos, a entrada no LP pode ser acompanhada, progressivamente, de uma outra redefinição de sua relação com os saberes. Essa redefinição corresponde o mais das vezes a recomposições identitárias e relacionais vividas pelo aluno e construídas no cotidiano. Por isso, se muitos alunos insistem no fato de "tornar-se grande" em LP, "tornar-se adulto" e "responsável", para além dos efeitos gerados pela instituição (o discurso professoral faz a apologia da "responsabilidade"), é uma maneira diferente de viver sua relação com a escola e com os saberes. Mas, olhando de mais perto, percebe-se que esse olhar sobre sua experiência de aluno procede amplamente da experiência escolar anterior que permite, para numerosos sujeitos, encontrar referências no universo específico que constitui o LP. Assim, se os alunos vivem positivamente sua relação com os saberes, é sempre em referência a uma escolaridade difícil experimentada no colégio: "Aqui eu me sinto bem, aprendo uma profissão mas vejo também que sou capaz de conseguir aprender matemática, enquanto que, no colégio, eu era nulo... aqui, sempre tiro catorze ou quinze em matemática, é que não sou tão burro assim". Essas afirmações que são de Armand, de 16 anos, aluno de primeira série de BEP "profissões de venda", revelam a dinâmica subjetiva e cognitiva de uma outra relação com os saberes, uma relação que não deixa de levar o aprendiz a "reler" sua história escolar. Mas essa releitura pode conduzir a um paradoxo, a saber, o reinvestimento nos saberes descontextualizados em detrimento dos saberes profissionais considerados como "não interessantes" ou pouco legítimos para serem ensinados. Assim, Benedicte, de 16 anos, diz que "sempre quis aprender a cozinhar", mas quando chegou aqui, disse: "não é possível que se cozinhe aqui, cozinhar não se aprende na escola". A inteligibilidade dessa crítica aparecerá posteriormente quando Benedicte evocará seu interesse por "suas" ciências, "suas" matemáticas, enquanto no colégio ela era nula. Descobrindo-se capaz de ter êxito nas matérias teóricas, ela superinveste nos saberes descontextualizados em detrimento dos saberes profissionais que, ao contrário dos alunos que aderem fortemente à forma prática dos saberes, the aparecem como uma "obrigação", uma coação, as "matérias nas quais é preciso de qualquer modo aprender".

Mais presente entre os alunos do BEP, e mais ainda nas especialidades do setor terciário, essa lógica na qual a forma escolar supera a forma profissional é no mais das vezes própria dos aprendizes que querem "ir longe nos estudos". Ela parece ter sua gênese no encontro entre a experiência escolar no colégio e a experiência no LP, sem ser obrigatoriamente a expressão de 
um projeto sócio-subjetivo de longa data: com efeito, tanto alguns alunos - de um bom nível escolar - dizem ter "preferido passar para o LP para ir mais longe", quanto outros evocam a mudança vivida com o encontro de saberes que fazem doravante sentido em si mesmos, ao mesmo tempo em que são remetidos a seu uso escolar.

Forma prática e forma escolar não esgotam o conjunto das formas de relação com os saberes. Existe uma terceira forma que se pode qualificar de "forma integrativa de si". Ela está presente em raros alunos. Essa forma oferece ao aprendiz a possibilidade de objetivar e tornar coerentes os saberes sem confundir os seus registros.

c) Uma forma integrativa e transformadora de si.

Poucos alunos com quem nos encontramos evocam os efeitos transformadores de si aos quais a apropriação do saber pode conduzir. Os raros alunos que acentuam esses efeitos são freqüentemente aqueles que descrevem com precisão e pertinência os conteúdos das matérias; são também mais levados a conferir aos saberes uma dimensão simbólica meta-prática e a não remetê-los à sua única finalidade pragmática ou utilitária. Aliás, esses alunos não opõem os saberes teóricos aos saberes profissionais (ou práticos). Ao mesmo tempo em que reconhecem sua especificidade, vêem neles mais um conjunto de conteúdos "complementares" e os situam como um núcleo que permite a apropriação do mundo e dos objetos e não como tendo um fim em si. Enfim, essa categoria de alunos não dissocia a experiência escolar da experiência da vida. Se os saberes escolares são identificados a um conteúdo diferente daquilo que se pensa "aprender na vida", eles constituem também uma "chave" que torna possível analisar situações vividas fora da escola. As opiniões de Daniel, de 16 anos, aluno de segunda série de BEP "madeiras e materiais associados", mostram uma grande lucidez e riqueza de análise relativas às finalidades (sentidos) dos saberes. "No liceu, o que aprendo me permite ver em que pé estou, é certo que os cursos nos ajudam a compreender melhor o que nos rodeia e a saber melhor quem somos e como chegamos até aqui... Os professores nos ajudam, mas cabe a nós fazermos um esforço... Eu não preciso que façam as coisas em meu lugar, basta somente me explicar algumas bases e cabe a mim fazer o esforço para compreender [...] Compreender? É ser capaz de analisar as situações aproveitando o tempo e se servindo do que se tem... por exemplo, quando leio um livro de literatura, procuro o sentido das palavras no dicionário e depois me sirvo delas quando devo construir frases interessantes... Há alunos que dizem que o que se faz no atelier é o que há de mais importante, é certo, todo mundo não é igual, mas eu penso que não temos curso de história por acaso... se estudamos história, é para compreender porque nos tornamos como somos... por exemplo, as eleições européias são o resultado de vários séculos de conflitos e, agora, fazemos a paz, sentamo-nos uns ao lado dos outros". Esse aluno que vai bem na escola vem de uma família de pais professores (o pai ensina tecnologia no colégio, a mãe é professora 
primária especializada em SES); parece mesmo que a média dos alunos é levada ao conhecimento do mundo e adota uma postura na qual se percebe como ator de sua experiência de aprender, sob um pano de fundo da transformação de si: "Para mim, vir à escola não é somente aprender uma profissão, é também me instruir com os outros e com o que nos é dito nos cursos... Eu não seria o mesmo se não tivesse ido à escola e, se aprendo coisas, é em primeiro lugar para mim... não quero ficar por fora quando ouço os outros discutirem... meus pais pensam que o que há de melhor é ter diplomas e ser grande, mas pode-se crescer aprendendo coisas e estando a par da vida". Mas, apesar da apologia dos saberes descontextualizados, Daniel não é levado a subestimar os saberes profissionais. Define-se como "alguém que aprende uma profissão para mais tarde e que se instrui para agora". Ele dirá igualmente que "a madeira é também uma coisa nobre, gosto muito da arte em madeira, nós fazemos essa arte porque estudamos as formas, vemos um pouco os móveis... Estudamos os estilos, tipo Regência ou Luís Felipe, isso também é história". Imagem ideal-tipo do que pode ser uma experiência "feliz" no LP, Daniel exprime uma forma integradora de relação com os saberes, pelo fato de não confundir os registros, não superestimar um conteúdo em detrimento do outro e pelo fato de conseguir transcender a forma prática inscrevendo-a em sua dimensão cultural e histórica.

Pode-se então observar, percorrendo algumas formas de relação com os saberes, que os alunos de LP definem sua experiência oscilando entre uma visão utilitária e um olhar mais nuançado relativo aos conteúdos escolares e profissionais. Se muitos deles insistem no caráter de obrigação de algumas matérias, na distância entre as matérias gerais e as profissionais, na pouca quantidade de estágios em empresas, muitos também vivem relações seletivas com os diversos saberes, de modo que num mesmo aluno podem coabitar uma crítica de certas matérias teóricas e uma tomada de distância a respeito de certas matérias profissionais ou tecnológicas. Assim, na interface da oposição entre os saberes teóricos e os saberes práticos, o aprendiz tenta encontrar uma coerência para os conteúdos, remetendo-os a projetos profissionais, à sua "personalidade" e a relações intersubjetivas socialmente situadas.

Mas a apreciação das formas de relação com os saberes convida a uma ampliação dos pontos de vista: com efeito, se observamos que o sentido dos saberes e as modalidades de mobilização frente à escola combinam uma pluralidade de elementos (subjetivos, institucionais, relacionais...), as entrevistas mostram também que as atividades profissionais próprias de cada especialidade se identificam, para o aprendiz, a "práticas significativas" na medida em que lhe mostram maneiras de fazer e aparecem como "reveladoras" de uma posição no espaço complexo das relações sociais e culturais que definem as aprendizagens práticas (ou profissionais). Por essa razão, a experiência escolar dos alunos de CAP ou de BEP diferenciam os aprendizes e os convidam a assumir uma postura específica (comprometida ou distante) a respeito de sua "identificação institucional". 


\section{As atividades profissionais: entre o compromisso subjetivo e o distanciamento}

A aprendizagem de uma profissão definitiva delimita fortemente a identidade dos alunos do liceu profissional. Essa identidade, ao evocar com insistência a profissão, é sobretudo o que é próprio dos alunos das especialidades industriais e daqueles que preparam um CAP. Contudo, considerando todas as carreiras, os que priorizam as aprendizagens profissionais para pensar-se como aprendizes são a maioria. Mas dizer que "no LP se aprende uma profissão" significa que o aluno se conforme aos papéis prescritos pela instituição? De uma maneira geral, pareceu-nos que por detrás da evocação da aprendizagem de uma profissão se perfilam diferentes lógicas, que traduzem graus diferentes de implicação face à formação, mas que exprimem necessariamente uma "relação de impregnação" que pode, se for o caso, ser associada a práticas sociais cotidianas pelo aluno. Por essa razão, é o próprio sentido das aprendizagens profissionais que tentamos destacar entre os alunos de CAP e de BEP, com o objetivo principal de mostrar que a maneira pela qual o aluno se pensa como aprendiz depende ao mesmo tempo das atividades específicas da especialidade e dos modos das relações sócio-subjetivas que a apropriação dessas atividades torna possível na vida cotidiana.

\section{a) As diferenças segundo as carreiras: os CAP e os BEP.}

Os saberes profissionais ensinados variam segundo a carreira. Assim, os alunos de CAP se confrontam com matérias profissionais muito próximas e complementares, o que é conforme aos objetivos desse diploma: formar futuros operários especializados. O efeito-carreira é manifesto entre os alunos de CAP na medida em que, mais do que os do BEP, eles se pensam como futuros operários e têm um conhecimento bastante preciso da "profissão" que serão conduzidos a exercer. Os alunos de CAP - cuja origem social já vimos - são o mais das vezes vindos do ensino especializado - se pensam como futuros operários e parecem mais comprometidos subjetivamente com o processo de aprendizagem da profissão (o comprometimento se manifesta pela forte identificação de si mesmo com a formação e pouco recuo crítico face às situações profissionais; eles são menos críticos a respeito da forma profissional).

Os alunos de BEP mantêm relações complexas com a profissionalização. Isso se deve a dois elementos fundamentais: de um lado, são escolarizados numa carreira que forma operários polivalentes, o que leva a uma certa imprecisão entre os alunos (muitos declaram "não saber a que emprego o BEP leva"); de outro lado, o público dos BEP vive uma forte dissociação entre os saberes teóricos e os saberes profissionais, o que conduz a adotar duas posturas dominantes: ou o aluno subscreve à forma escolar e, nesse caso, é levado a desvalorizar a forma profissional, o que é uma maneira de neutralizar os efeitos de uma orientação não escolhida identificando seu 
futuro a uma entrada numa "primeira adaptação"(seção mais teórica) ou então o aluno subscreve à forma profissional valorizando-a em detrimento dos saberes teóricos (a oposição não é tão radical; na realidade, os alunos são levados a selecionar as matérias e até mesmo, no interior de cada matéria, a selecionar os conteúdos que lhes parecem importantes seja para a vida ativa, seja no caso de pretenderem uma entrada no bacharelado profissional).

O efeito-carreira não é interpretado somente sob o ângulo dos conteúdos escolares, mais descontextualizados no BEP do que no CAP (o BEP hoje em dia é um estágio transitório em direção a uma qualificação superior). Ele é apreciado por sua vez pela junção entre os fatos contextuais (ou objetivos) que concernem ao conteúdo das formações e os fatos biográficos, que remetem essencialmente à história e ao itinerário sócio-escolar do aluno. Assim, certos alunos de CAP, vindos da terceira série geral ou tecnológica, mostram-se mais distantes em relação à sua formação, como se a orientação recebida (eles deveriam preparar um BEP ao sair do colégio) os conduzisse a não se pensarem como "caldeireiros", "servidores de bar", ou "costureira", e a esperar "fazer outra coisa depois do CAP (opinião de Carole, de 17 anos, aluna de CAP “café-brasseria”). Para Laurent, de 16 anos, "o CAP de 'metais' não serve para nada, porque hoje em dia, quando se pode, é preciso no mínimo um BEP por exemplo, em eletrônica". Às vezes, a tomada de distância em relação à sua formação está estreitamente ligada a decepções e tensões familiares, como anuncia Cédric, aluno de primeira série de CAP, "marcenariaagenciamento": "Eu poderia ter trabalhado melhor e não estar aqui... meus irmãos fizeram uma segunda de liceu, isto é, eles fizeram um BEP em mecânica de automóveis... Talvez, com o tempo, conseguirei vencer para ter uma outra situação... uma boa situação".

A impregnação de saberes profissionais fica manifesta entre os alunos, mesmo se eles tomam maior ou menor distância em relação à profíssão que dizem aprender. Parece que a especialidade exerce um papel discriminatório entre os alunos, o que é uma maneira de pensar as formas de relações com os saberes através do sentido conferido às atividades profissionais propriamente ditas. Assim, o aluno pode dizer que não gosta de cozinha como profissão mas achar que a prática de cozinha é "interessante porque serve para a casa". Finalmente, o sentido de uma aprendizagem profissional é avaliado segundo as finalidades sociais e/ou profissionais que os alunos identificam ou associam ao seu futuro.

b) O efeito-especialidade: uma maneira de repensar a relação sócio-subjetiva com a aprendizagem profissional.

Os saberes profissionais delimitam para o aprendiz um domínio de atividade significando a especialidade e a abertura da escolaridade para o mercado de trabalho. Significam igualmente a hierarquia e as diferenças sociais existentes entre as "profissões". De imediato, o sentido atribuído pelos alunos a uma formação - lembremos que a maioria dos alunos de LP evocam, 
em primeiro lugar, a especialidade, para falar do que pensam aprender no LP -é estreitamente ligada aos valores sociais que envolvem os domínios profissionais e a profissões para as quais se considera que o liceu deve prepará-los.

Raymond, de 17 anos, aluno de BEP "eletrotécnica", faz parte dos alunos que se identificam com a especialidade e põem em causa a utilidade dos saberes teóricos. Ele fala, nesses termos, de sua relação com a formação: "Para mim, eu me vejo eletricista porque na vida de todos os dias, se tem necessidade de eletricidade, às vezes acontece que ajudo meu pai quando ele faz trabalhos [...]. Agora todo mundo que conheço pode me pedir para dar uma mão para consertar os fusíveis, fazer funcionar um circuito elétrico ou consertar um aparelho de lavar". Contudo, esse aluno nos dirá ter "pedido um BEP de hotelaria mas não foi aceito". Pode-se então considerar que a experiência escolar impregna o adolescente e contribui para lhe abrir novas perspectivas, a definir relações específicas com seu ambiente socio-relacional e familiar. Assim, Raymond se pensa como "eletricista", mas efetua uma aproximação entre as aprendizagens profissionais e as solicitações sociais que lhe dão, em retorno, uma forma de "reconhecimento" de seu "saber".

Para Mélanie, aluna de BEP "profissões de venda", "a profissão de vendedora permite encontrar pessoas, colocar-se em questão, porque antes eu não pensava em nada a não ser em sair da escola, eu me entediava e era teimosa... quando me diziam alguma coisa, ficava agressiva... aqui, em vendas, aprende-se ter boa aparência e se tenta refletir sobre o que se faz... a professora e os estágios me mostraram bem que os clientes também tinham expectativas e que se deve considerá-las..." É certo que essa aluna nos dirá que sua idade, 18 anos, e o casamento próximo fizeram dela "uma outra pessoa" (o que mostra que a experiência escolar está estreitamente ligada a outros processos associados ao contexto escolar, mas à vida relacional em geral), mas percebe-se que a especialidade, com suas exigências institucionais e normativas, transforma o aprendiz e o leva a pensar-se diferentemente.

O efeito-especialidade é observado entre os alunos que optam por uma lógica profissional. É igualmente observado, mas sob outra forma, entre aqueles que se pensam num alhures, que não se identificam seu futuro à formação profissional atual. Mathilde, de 16 anos, aluna de primeiro ano de BEP "carreiras sanitárias e sociais", diz ter "ficado chocada com as pessoas idosas, como elas vivem em condições difíceis... elas esperam assim o fim de seus dias, mas não é simples... para mim, eu não poderia trabalhar desse jeito, não se pode ser sensível... de qualquer maneira, eu quero ser educadora de crianças pequenas, o estágio me permitiu ver, de qualquer modo, como vivem as pessoas de idade em casas de repouso". Somos então conduzidos a observar que a especialidade, colocando o aluno diretamente diante das práticas profissionais, vistas no LP ou no estágio, o coloca "diante da verdade" no que concerne ao que o afasta da forma escolar e que o inscreve nas relações complexas com as atividades de significado social e subjetivo proteiforme. No caso de Mathilde, as atividades profissionais ligadas aos cuidados com pesso- 
as idosas são vistas como "degradantes", "pouco interessantes” em relação ao seu projeto profissional, que ela define em torno das profissões que lidam com a infância ("pelo menos, com as crianças, pode-se fazer com elas coisas interessantes, atividades de animação e de desenvolvimento... o que as prepara para a escola maternal").

O efeito-especialidade é avaliado como estabelecimento de uma relação de um aprendiz com atividades que possuem significações e finalidades sociais e subjetivas. Esse estabelecimento de relação varia segundo os conteúdos da formação, de modo que se podem deduzir efeitos variados segundo os saberes profissionais usem ou não a forma escritural (lugar da escrita nas atividades), sejam mais ou menos valorizados na escala das classificações sociais das "profissões"(estatuto da especialidade, a mecânica de automóveis ou a eletrotécnica são mais valorizadas do que a caldeiraria ou a manutenção de locais) e as relações complexas entre a história do aluno e as atividades praticadas.

O efeito da especialidade sobre a relação com os saberes depende das atividades profissionais. Assim, aprender contabilidade põe o aluno diante de atividades que combinam estreitamente a forma escrita (ou escolar) e a forma prática, de sorte que o aprendiz pode mais facilmente identificar os laços existentes entre as matérias, enquanto o aprendiz de cozinha ou de manutenção de locais solicita outra relação com o aprender: para Sandra, aluna de CAP "empregado técnico de coletividades", "quando se cozinha ou se faz limpeza, aprende-se coisas diferentes da escola [...] a gente aprende a se virar na vida de todos os dias... se vê também que são coisas que vão nos servir para o trabalho... eu não sabia que a limpeza se aprendia na escola, mas no estágio, se vê que é útil... aprendi a cor dos produtos e a higiene do que comemos [...] o que aprendi no CAP servirá para minha família quando eu fundar um lar". Arnaud, aluno de segunda série de BEP "profissões de contabilidade", exprime de modo diferente o efeito-especialidade: "O que é bom no liceu profissional são os estágios [...] Sei agora como se faz a contabilidade, mas são coisas que se aprende no curso, em classe, é certo que vemos direito e economia, se aprende a fazer um quadro, a gerir estoques... no estágio, aplico tudo isto e aprendo ainda mais". Se Arnaud, diferentemente de Sandra, não se apropria dos saberes integrando-os aos usos domésticos ou cotidianos, ele exprime, ao seu modo, o efeito-especialidade tornando-se "consciente" do fato de que o domínio da contabilidade exige uma outra relação com o aprender, em particular com a aquisição de conhecimentos econômicos e jurídicos que pertencem à forma escolar. Assim, nas especialidades do setor terciário, a maioria dos alunos percebe a necessidade de uma apropriação de saberes descontextualizados (mesmo sendo finalizados profissionalmente) em vista da apropriação de saberes práticos. Esse não é o caso das especialidades industriais (assim como de certas especialidades do setor terciário tais como cozinha, higiene de locais...) que, pela especificidade das atividades propostas, contribuem para a confusão entre a aprendizagem de um "ofício" e seu 
exercício (os alunos dos LP industriais, na maioria do sexo masculino, "gostariam de ter apenas o atelier, os cursos não servem para nada, o professor fala enquanto nós queremos fazer coisas") e, portanto, para acentuar a distância entre a forma escolar e a forma profissional.

Uma sociologia das formas de relação com os saberes ainda está por ser circunscrita. A pesquisa junto a alunos de liceus profissionais nos ensinou que o sentido das aprendizagens é analisado a partir das relações complexas que unem ou separam a experiência escolar da experiência social dos alunos. Ela nos ensina igualmente que a relação entre a socialização e as aprendizagens nos convida a um aprofundamento: se os alunos só aprendem na relação com os professores, com os pares e com a família, eles não se pensam fora da especialidade e da carreira de formação. Assim, o efeito-formação identifica fortemente, na sua opinião, o que eles pensam aprender no LP. Por essa razão, uma sociologia das formas de relação com os saberes é levada a trabalhar a questão do sentido social e subjetivo com o qual as atividades se revestem e mobilizam os alunos. Por esse procedimento, poder-se-á tentar aproximar uma sociologia dos currículos escolares de uma sociologia da experiência escolar, o que é uma maneira de aproximar o contexto objetivo, que se considera que "forma" um público, e os elementos subjetivos que estão ligados às biografias (ao mesmo tempo socais e singulares).

Além disso, a particularidade do ensino no liceu profissional, pelo fato de ser escolar e profissional, convida a perscrutar a especificidade de uma relação complexa entre a vontade de se libertar de uma orientação não escolhida, para uns, e a constituição progressiva de uma lógica de "profissionalização" que ainda está por ser explorada do lado dos novos aprendizes ${ }^{8}$. Nessa perspectiva, poder-se-á igualmente relativizar a hipótese de um êxito escolar que seria estreitamente dependente de uma objetivação e mobilização no absoluto dos saberes (os alunos os finalizam sempre em relação a usos, inclusive usos relacionais e simbólicos, "aprender para discutir com os outros e mostrar que sabemos coisas", por exemplo). Além do mais, a fraca mobilização dos alunos do LP em relação aos saberes fora do liceu, em casa principalmente, leva à questão seguinte: como explicar o êxito escolar entre alguns alunos que dizem "aprender tudo no LP”? Essa interrogação conduz a supor que é no interior do LP, a respeito das práticas pedagógicas, ${ }^{9}$ mas igualmente em relação à atenção e ao "interesse" construídos pelo aluno, que pode ser explicada a variedade dos itinerários escolares e, portanto, o caráter variado das formas de relação com os saberes.

\section{Nota sobre o sistema escolar francês}

Após a escola primária, os alunos entram no colégio, no qual a escolaridade dura quatro anos (sexta, quinta e quarta séries, numa contagem decrescente, ao contrário do sistema brasileiro). O colégio tornou-se "único" desde 1975, o que implica que os alunos só fazem escolhas de orientação ao
${ }^{8}$ É certo que não se poderia identificar a profissionalização dos indivíduos em situação de trabalho (cf. Dubar \& Tripier, 1998), com a dos alunos de LP para os quais o termo "profissionais" é inadequado. Entretanto, avanços heurísticos poderiam ser realizados se nos propomos a estudar a maneira pela qual os ensinos dispensados tentam "tornar profissionais" os alunos e o modo pelo qual estes se apropriam dos saberes e do saber fazer, integrando-os ou não num projeto de formação ao qual eles identificam seu futuro de operário ou de técnico.

${ }^{9}$ A questão das relações pedagógicas pode ser tratada a partir de vários eixos dentre os quais o da relação com os saberes entre os professores. Esse ponto, que tratamos em nossa pesquisa de doutorado, será objeto de investigações mais aprofundadas indo além da profissionalização (cf. Hirshhorn, 1993) para ver o que é que, da história social e escolar do professor, participa das modalidades mesmas da definição do público de LP, da organização dos cursos e de solicitação de aprendizes. A complexidade dos estatutos dos professores de LP (cf. Agulhon, 1994) parece nos oferecer a possibilidade de uma análise fina, opondo globalmente os professores de matérias gerais, vindos na maioria da universidade, e os professores das matérias tecnológicas e profissionais, vindos frequentemente do mundo industrial depois de uma escolarização em LP ou em liceu técnico. 
terminar a última série do colégio (terceira). Ao final do colégio, os alunos são orientados seja para a segunda série geral e tecnológica, que leva, ao final de três anos, seja ao bacharelado geral ou tecnológico (no sistema francês, portanto, o bacharelado corresponde ao nosso ensino médio), seja à segunda profissional, num liceu profissional, para preparar um CAP ou um BEP (respectivamente "Brevê de estudos profissionais e Certificado de estudos profissionais). Após o BEP, e às vezes após um CAP, uma parte dos alunos - mais ou menos 15 a $16 \%$ - integrará uma primeira série de adaptação tendo em vista preparar um bacharelado tecnológico; de outro lado, para aproximadamente $40 \%$ dos alunos titulares de um BEP a orientação para uma primeira profissional lhes permitirá preparar um bacharelado profissional. Esse bacharelado, criado em 1985, tem como finalidade sobretudo a formação de um operário altamente qualificado e a inserção profissional dos formados.

Recebido para publicação em setembro/2001

Tradução de Maria das Graças de Souza

KEY WORDS:

technical teaching, school knowledge, learner subject, school context, socialization.
JELLAB, Aziz. CAP and BEP students and school subject content: a contribution to sociology of the forms of relationship among different fields of knowledge. Tempo Social; Rev. Sociol. USP, S. Paulo, 14(1): 109-136, May 2002.

ABSTRACT: This paper discusses the relationship between socialization and knowledge content in the carriers of technical teaching in France. It is a sociological analysis of school experience based on two hypothesis: firstly, one that considers the student as an original synthesis of a social history and secondly, one that takes into account the importance of school context in the building of meaning of knowledge and learning.

\section{REFERÊNCIASBIBUOGRÁFICAS}

Agulhon, C. (1994) L'enseignement professionnel. Quel avenir pour les jeunes? Paris, Éditions de l'Atelier.

(1997) Les relations formation-emploi, une quête sans fin: les formations à la plasturgie. Sociologie du travail, $\mathbf{3}$.

BALlion, R. (1993) Le lycée, une cité à construire. Paris, Hachette-Education.

B ARRÈre, A. (1997) Les lycéens au travail. Paris, PUF. 
BAutier, E. \& Rochex, J-Y. (1997) Apprendre: les malentendus qui font la différence. In: TerraIL, Jean-Pierre (éd.). La scolarization de la France. Paris, La Dispute.

$\&$ . (1998) L'expérience scolaire des nouveaus lycéens. Paris, A. Colin.

BeILlerot, J. (1996) Désir, désir de savoir, desir d'apprendre. In: .et alii. (éds.) Pour une clinique du rapport au savoir. Paris, L'Harmattan.

Benoît-Guilbot, O. (1990) La recherche d'emploi: stratégies, qualification scolaire ou professionnelle et qualification sociale. Sociologie $d u$ travail, 32.

Berger, P. \& LuckMAnN, T. (1966) La construction sociale de la réalité. Paris, Méridiens-Klinksieck.

Bertaux, D. (1997) Les récits de la vie. Paris, Nathan.

Bouyx, B. (1997) L'enseignement technologique et professionnel. Paris, Anthropos, La Documentation Française.

Charlot, B. (1997) Du repport au savoir: élements d'une théorie. Paris, Anthropos-Economica.

(1999) Le rapport au savoir en milieu populaire: une recherche dans le lycéens professionnels de banlieu. Paris, AnthroposEconomica.

., Bautier, E. \& Rochex, J.-Y. (1992) École et savoir dans le balieues et ailleurs. Paris, A. Colin.

Demazière, D. \& Dubar, C. (1997) Analyser les entretiens biographiques. Paris, Nathan.

Dubar, C. (1991) La socialization. Construction des identités sociales et professionnelles. Paris, A. Colin.

\& TrIPIER, P. (1998) Sociologie des professions. Paris, A. Colin.

Dubet, F., (1991) Les lycéens. Paris, Seuil.

. (1994) Sociologie de l'expérience. Paris, Seuil.

., Cousin, O. \& Guillemet, J.-P. (1991) Sociologie de l'expérience lycéenne. Revue Française de Pédagogie, 94.

\& Martuccelli, A. (1996) Á l'école. Sociologie de l'expérience scolaire. Paris, Seuil.

Duru-Bellat, M. \& Mingat, A. (1988) Le déroulement de la scolarité au collège: le contexte "fait des différences". Revue Française de Sociologie, 29.

FELouzIs, G. (1994) Le collège au cotidien. Paris, PUF.

Grafmeyer, Y. \& Joseph, L. (1979) L'école de Chicago. Paris, Champ Urbain. 
Grignon, C. (1971) L'ordre des choses. Paris, Minuit.

HiRshHORN, M. (1993) L'ère des enseignants. Paris, PUF.

JELlaB, A. (1996) L'insertion sociale comme préalable à l'insertion professionnelle. L'homme et la Société, 130.

. (1997 a) Le travail d'insertion en mission locale. Paris, L'Harmattan.

. (1997b) La mission locale face aux jeunes: quelle socialization pour quelle insertion? Cahiers Internationaux de Sociologie, 102.

. (1998) De l'insertion à la socialization. mission locale, jeunes 16-25 ans et problématique de l'exclusion. Formation-Emploi, 62.

LAHIRE, B. (1995) Tableaux de famille. Paris, Gallimard-Seuil. . (!998) L'homme pluriel. Les ressorts de l'action. Paris, Nathan.

LAURENS, J. P. (1992) 1 sur 500. La réussite scolaire en milieu populaire. Toulouse, Presses Universitaires du Mirail.

Michelat, G. (1975) L'entretien non directif. Revue Française de Sociologie, 16.

Monaco, G. (1993) L'alternance école-production. Paris, PUF.

Nicole-Drancourt, C. (1994) Mesurer l'insertion professionnelle. Revue Française de Sociologie, 34.

Pelpel, D. \& Troger, V. (1993) Histoire de l'enseignement technique. Paris, Hachette-Education.

Rayou, P. (1994) La cité invisible. Essai sur la socialization politique des lycéens. Thèse (doctorat de sociologie), EHESS.

TAnguy, L. (1991) L'enseignement professionnel. Des ouvriers aux techniciens. Paris, PUF.

TerraIL, J-P. (1990) Destins ouvriers. La fin d'une classe? Paris, PUF.

VINCENT, G. et alii. (1994) L'éducation prisionnière de la forme scolaire? Lyon, PUL. 